VOL. 2

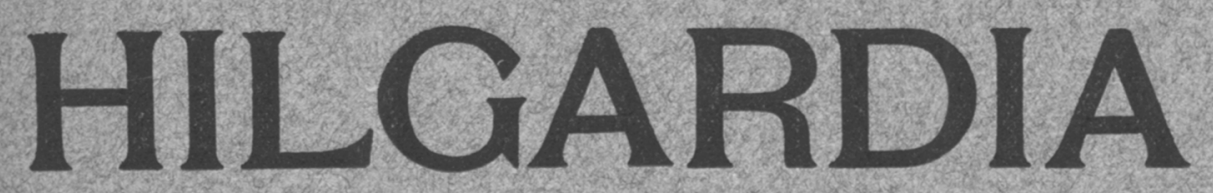

A Journal of Agricultural Science PUBLISHED BY THE

California Agricultural Experiment Station

\title{
CONTENTS
}

Acute Infection of Chicks and Chronic Infection of the Ovaries of Hens Caused by the Fowl-Typhoid Organism

J. R. BEACH AND D. E. DAVIS 


\title{
EDITORIAL BOARD
}

\author{
E. D. MERRILL, Sc.D.
}

J. T. Barrett, Ph.D. Plant Pathology

F. T. Bioletti, M.S.

Viticulture

W. H. Chandler, Ph.D.

Pomology

R. E. Clausen, Ph.D.

Genetics

H. E. Erdman, $\mathrm{Ph} . \mathrm{D}$. Agricultural Economics

H. M. Evans, A.B., M. D. Nutrition

G. H. Hart, M. D., D.V.M. Veterinary Science

D. R. Hoagland, M.S.

Plant Nutrition

A. H. Hoffman, E.E. Agricultural Engineering
W. L. Howard, Ph. D.

Pomology

H. A. Jones, Ph. D.

Truck Crops

W. P. Kelley, Ph.D.

Chemistry

W. A. Lippincott, Ph.D.

Poultry Husbandry

C. S. Mudge, Ph. D.

Bacteriology

H. J. Quayle, M.S.

Entomology

H. S. Reed, Ph. D.

Plant Physiology

W. W. Robbins, Ph.D.

Botany

F, J. Veihmeyer, C.E.

Irrigation 


\title{
HILGARDIA
}

\author{
A JOURNAL OF AGRICULTURAL SCIENCE \\ PUBLISHED BY THE
}

CALIFORNIA AGRICULTURAL EXPERIMENT STATION

VOL. 2

MARCH, 1927

No. 12

\section{ACUTE INFECTION OF CHICKS AND CHRONIC INFECTION OF THE OVARIES OF HENS CAUSED BY THE FOWL-TYPHOID ORGANISM*}

\author{
J. R. BEACH $\dagger$ AND D. E. DAVIS $\ddagger$
}

\section{INTRODUCTION}

The earliest authentic descriptions of fowl typhoid are those of Klein ${ }^{1}$ in 1889, in England, and of Moore ${ }^{2}$ in 1895-96, in the United States. Klein designated the disease as infectious enteritis and the causative organism, Bacillus gallinarum. Moore called the disease infectious leukemia of fowls and the causative organism Bacterium sanguinarium.ई It has since been determined that these investigators studied the same disease, which is now known as fowl typhoid and has become recognized as an important cause of mortality of adult fowls throughout the world.

* A brief résumé of these studies was contained in the California Agr. Exp. Sta. Ann. Rpt. 1924-25: 72.

† Assistant Professor of Veterinary Science and Associate Veterinarian in the Experiment Station.

$\ddagger$ Junior Veterinarian in the Experiment Station. Resigned November 1, 1926.

$\S$ In Bergey's Manual of Determinative Bacteriology (Williams and Wilkins Company, Baltimore, Maryland, 1923), Bacterium sanguinarium (Moore) is classified as Eberthella sanguinaria (Moore) and is said to be associated with cholera in chickens. The species of organisms stated to be associated with fowl typhoid are Eberthella jeffersonii (Hadley), Eberthella pfaffi (Hadley), and Eberthella rettgeri (Hadley). Klein's Bacillus gallinarum is classified as Pasteurella avicida (Perroncito), the cause of fowl cholera. This classification is apparently based largely upon the studies of Hadley reported in Rhode Island Agr. Exp. Sta. Bul. 174. This publication, however, presents $E$. jeffersonii, E. pfaffi, and $E$. rettgeri as new bacterial types, differing from both the fowl-cholera and fowl typhoid organisms. Bact. sanguinarium (Moore) and B. gallinarum (Klein) are regarded as identical and as the etiological agent of fowl typhoid. It would appear, therefore, that the fowl-typhoid organism is improperly classified in the above mentioned manual. For this reason Bact. sanguinarium (Moore), the name of the fowl-typhoid organism in common usage in the United States, is used in this paper. 
Some investigators observed a marked similarity between Bact. sanguinarium and Bact. pullorum,* the cause of bacillary white diarrhea of chicks. As a result, extensive comparative studies of the two species were made especially by Taylor, ${ }^{3}$ Smith and Tenbreeck, ${ }^{4}$ Rettger and Koser ${ }^{5}$ Goldberg, ${ }^{6}$ and Hadley. ${ }^{7}$ These investigators concluded that the two organisms were indistinguishable in their serologic reactions but that there were sufficient differences in their action on carbohydrate media, in their other cultural characteristics, and in their morphology to establish the identity of the two species.

References in the literature to fowl typhoid are numerous. The disease, however, has nearly always been described as an acute infection of mature fowls, little consideration being given to the rôle that Bact. sanguinarium might play in causing mortality among young chicks.

The organism in recent years has been recovered from dead chicks by several investigators and it therefore can no longer be regarded of importance only in connection with fowl typhoid of adults. Panisset and Verge $^{8}$ in 1924 reported an epizootic among a small flock of chicks in France in which they isolated an organism closely resembling Bact. sanguinarium. Stafseth in Michigan, Bushnell in Kansas, and Beaudette in New Jersey have stated in personal communications that they have occasionally isolated Bact. sanguinarium from chicks which they suspected had died from bacillary white diarrhea. Beaudette ${ }^{9}$ in 1925 reported the isolation of the organism both from young chicks and the ovary of a hen and he stated that 9 of 66 hens in the same flock reacted to an agglutination test with Bact. pullorum or Bact. sanguinarium antigens. In 1926, Doyle ${ }^{10}$ reported similar observations regarding the occurrence of the infection in chicks and hens. He also stated that the examination of 140 eggs from 9 reacting hens showed them to be free from Bact. sanguinarium. Disease of baby chicks due to Bact. sanguinarium was first observed in this laboratory in May, 1921, in chicks submitted for diagnosis. Clinically and in all other respects the disease resembled bacillary white diarrhea. Since then the organism has been occasionally encountered in routine bacteriological examinations of chicks.

In November, 1924, opportunity was afforded to make a detailed study of an outbreak of disease due to Bact. sanguinarium in a lot of chicks which had been obtained for experimental purposes. The conditions under which the outbreak occurred made it seem possible that the infection was acquired by a transmission cycle identical with that of Bact. pullorum. Investigations were undertaken to determine whether this suspicion was well founded.

* Classified as Salmonella pullora in Bergey's Manual of Determinative Bacteriology, p. 218. 


\section{THE OUTBREAK OF DISEASE IN BABY CHICKS}

On November 14, 1924, 145 chicks were obtained from a commercial hatchery for use in a coccidiosis control experiment. These chicks, all of which appeared vigorous on arrival, had been shipped in new boxes immediately upon removal from the incubator and were about thirtysix hours old when received. They were placed in pens which not only had been thoroughly disinfected but also had not previously contained poultry. The electric hovers, mash hoppers, and drinking fountains used were new ánd had also been disinfected. These chicks, therefore, were not exposed to infection of any kind except that which might have been present in the incubator or within or on the shell of the egg from which they were hatched.

The day following that on which the chicks were received, when they were about 60 hours old, the death of one chick occurred. Bact. sanguinarium was isolated in pure culture. Deaths from this cause continued and became so numerous that the coccidiosis control experiment for which the chicks were secured was abandoned. The outbreak of the disease due to Bact. sanguinarium, however, proved of equal interest and these chicks were, therefore, held for study and observation.

\section{TABLE 1}

Record of Mortality and Results of Post-mortem Examination of One Hundred aNd Forty-five Chicks Received November 14, 1924

\begin{tabular}{|c|c|c|c|c|c|c|c|c|c|c|}
\hline \multirow{2}{*}{ Time of death } & \multirow{2}{*}{$\begin{array}{c}\text { Num- } \\
\text { ber } \\
\text { died }\end{array}$} & \multirow{2}{*}{$\begin{array}{l}\text { Per } \\
\text { cent } \\
\text { died }\end{array}$} & \multicolumn{2}{|c|}{$\begin{array}{l}\text { Abnormal } \\
\text { liver* }\end{array}$} & \multicolumn{2}{|c|}{$\begin{array}{l}\text { Unabsorbed } \\
\text { yolk }\end{array}$} & \multicolumn{2}{|c|}{$\underset{\substack{\text { Bacterium } \\
\text { sanguinarium } \\
\text { isolated }}}{ }$} & \multicolumn{2}{|c|}{$\begin{array}{c}\text { Bacteriological } \\
\text { examination } \\
\text { negative }\end{array}$} \\
\hline & & & $\underset{\text { ber }}{\text { Num- }}$ & $\begin{array}{l}\text { Per } \\
\text { cent }\end{array}$ & $\underset{\text { ber }}{\text { Num- }}$ & $\begin{array}{l}\text { Per } \\
\text { cent }\end{array}$ & $\underset{\text { ber }}{\text { Num- }}$ & $\begin{array}{l}\text { Per } \\
\text { cent }\end{array}$ & $\underset{\text { ber }}{\text { Num- }}$ & $\begin{array}{c}\text { Per } \\
\text { cent }\end{array}$ \\
\hline First week. & 29 & 20.0 & 29 & 100.0 & 28 & 96.5 & 27 & 93.1 & 2 & 6.9 \\
\hline Second week & 23 & 15.8 & 22 & 95.6 & 14 & 60.8 & 22 & 95.6 & 1 & 4.3 \\
\hline Third week. . & 6 & 4.1 & 2 & 33.3 & 3 & 50.0 & 4 & 66.6 & 2 & 33.3 \\
\hline After third week.. & 21 & 14.5 & 4 & 19.0 & 2 & 9.5 & 4 & 19.0 & 17 & 80.9 \\
\hline Total......... & 79 & 54.4 & 57 & 72.1 & 47 & 59.5 & 57 & 72.1 & 22 & 27.8 \\
\hline
\end{tabular}

* Abnormalities consisted of uniformly yellowish or mottled yellow and red discoloration or uniformly pale without any marked discoloration.

A careful autopsy and bacteriological examination was made of each chick that died. Microscopic, biochemic, and serologic methods were used for identification of cultures. Those that consisted of Gramnegative non-motile rods; that produced acid but no gas in dextrose, 
mannite and maltose broth and did not ferment lactose and saccharose broth; and that were agglutinated by positive Bact. pullorum and Bact. sanguinarium serum but not by positive $B$. avisepticus serum were considered to be Bact. sanguinarium.

Table 1 gives a record of the mortality and results of post-mortem examination of the chicks which died before they were 45 days old.

\section{DISCUSSION OF BABY CHICK MORTALITY}

The mortality in this lot of 145 chicks during the first 45 days of their lives was 79 , or 54.4 per cent. Bact. sanguinarium was isolated from 57, or 72.1 per cent, of those that died, or 39.3 per cent of the total number of chicks.

Forty-nine, or 85.9 per cent, of the deaths from fowl-typhoid infection occurred during the first two weeks. Failure to recover the organism was encountered in only 3 of the 52 chicks which died during this period. Of the 27 chicks which died after the second week, Bact. sanguinarium was recovered from 8 , or 29.6 per cent.

The distribution of abnormal livers and unabsorbed yolks with respect to the age of the chicks at the time of death corresponded closely to the incidence of Bact. sanguinarium infection. Abnormalities of the liver were found in 51, or 98.0 per cent of the 52 which died during the first two weeks and in 6 , or 22.2 per cent, of those which died later. Unabsorbed yolk was present in 42 , or 80.7 per cent, of those which died during the first two weeks and in 5, or 18.5 per cent, of those which died later.

It can be seen that this outbreak of disease due to Bact. sanguinarium resembled in all respects bacillary white diarrhea of baby chicks due to Bact. pullorum infection.

\section{OBSERVATIONS ON THE SURVIVORS}

Twenty-five of the survivors, 20 females and 5 males, were kept for further study. An agglutination test with Bact. sanguinarium antigen was made on the blood serum of each bird when they were six, eight, and twelve months of age. No reactions occurred. One bird died when seven months old. No pathological changes were found in the ovary and a bacteriological examination was negative. One bird died when ten months of age. The port-mortem examination showed three small abnormal-appearing yolks in the ovary. The bacteriological examination of the liver, heart blood, and the three 
yolks was negative. Since negative results were obtained from the three agglutination tests and no evidence of Bact. sanguinarium infection was found in the two birds which died, no further tests or examinations were made of the remaining birds.

While these studies failed to demonstrate that the survivors of an outbreak of fowl typhoid in baby chicks become chronic carriers of Bact. sanguinarium they do not preclude the possibility that some did become carriers, since only 25 of the 66 survivors were retained for observation.

\section{INFECTION OF THE OVARIES OF HENS}

As stated at the outset, the only possible sources of the infection in the chicks seemed to be either the incubators in which or the eggs from which they were hatched. Since the nursery trays and nursery tray cloths of the incubators were cleaned between hatches and little complaint of chick mortality had been experienced by the hatchery owner, the eggs seemed the most likely source of the infection. This suggested that chronic ovarian infection with Bact. sanguinarium might exist in breeding fowls and be transmitted to chicks through the egg in the same manner as Bact. pullorum. If this should prove to be true, it seemed possible that the carriers of the infection might be detected by means of the agglutination test. Permission was obtained to collect blood samples for the agglutination test from a portion of the flock of 1300 birds that produced the eggs from which the chicks were hatched.

On December 12, 1924, blood was drawn from 196 of the 1300 birds. The agglutination test was made on each blood sample with antigens prepared from both Bact. pullorum and Bact. sanguinarium. Positive reactions were obtained with 32 or 16.3 per cent.

The degree of agglutinations obtained with the positive sera is given in table 2.

An analysis of table 2 shows:

- 1. Partial or complete agglutination with both antigens was obtained with 29 of the 32 samples.

2. Complete agglutination with both antigens in at least one dilution was obtained with 22 samples.

3. In three instances (Nos. 444, 461, 479) there was complete agglutination with Bact. pullorum antigen but only partial with Bact. sanguinarium antigen. Repetition of the tests with these samples gave the same results. 
4. One sample (No. 416) gave complete agglutination with Bact. sanguinarium antigen but only partial agglutination with Bact. pullorum antigen. Repetition of the test with this sample gave the same result.

TABLE 2

The Reactions to the Agglutination Test of the Positive Sera

\begin{tabular}{|c|c|c|c|c|c|c|c|c|c|}
\hline \multirow{2}{*}{$\begin{array}{l}\text { Bird } \\
\text { No. }\end{array}$} & \multicolumn{2}{|c|}{$\begin{array}{l}\text { Bact. pullorum } \\
\text { antigen }\end{array}$} & \multicolumn{2}{|c|}{$\begin{array}{l}\text { Bact. sanguinarium } \\
\text { antigen }\end{array}$} & \multirow{2}{*}{$\begin{array}{l}\text { Bird } \\
\text { No. }\end{array}$} & \multicolumn{2}{|c|}{$\begin{array}{l}\text { Bact. pullorum } \\
\text { antigen }\end{array}$} & \multicolumn{2}{|c|}{$\begin{array}{c}\text { Bact. sanguinarium } \\
\text { antigen }\end{array}$} \\
\hline & $\begin{array}{l}0.02 \mathrm{mil} \\
\text { serum }\end{array}$ & $\begin{array}{l}0.01 \mathrm{mil} \\
\text { serum }\end{array}$ & $\begin{array}{c}0.02 \mathrm{mil} \\
\text { serum }\end{array}$ & $\begin{array}{l}0.01 \mathrm{mil} \\
\text { serum }\end{array}$ & & $\begin{array}{c}0.02 \mathrm{mil} \\
\text { serum }\end{array}$ & $\begin{array}{c}0.01 \mathrm{mil} \\
\text { serum }\end{array}$ & $\begin{array}{l}0.02 \mathrm{mil} \\
\text { serum }\end{array}$ & $\underset{\text { serum }}{0.01 \mathrm{mil}}$ \\
\hline 304 & + & $\mp$ & + & - & 395 & + & + & + & + \\
\hline 315 & + & $\neq$ & + & $\neq$ & 415 & + & - & + & - \\
\hline 320 & $\neq$ & + & $\neq$ & \pm & 416 & $\mp$ & - & + & - \\
\hline 325 & \pm & - & $\mp$ & - & 423 & + & $\mp$ & - & - \\
\hline 341 & $\neq$ & $\neq$ & $\neq$ & $\neq$ & 425 & $\neq$ & + & $\neq$ & $\neq$ \\
\hline 349 & + & - & - & - & 432 & $\mp$ & $\mp$ & \pm & - \\
\hline 350 & + & - & - & - & 435 & + & $\mp$ & + & $\mp$ \\
\hline 354 & $\neq$ & $\neq$ & $\neq$ & $\neq$ & 443 & + & + & + & \pm \\
\hline 365 & + & + & $\neq$ & $\neq$ & 444 & $\neq$ & + & \pm & - \\
\hline 368 & $\neq$ & + & $\neq$ & + & 452 & $\neq$ & $\neq$ & $\neq$ & $\neq$ \\
\hline 371 & $\neq$ & $\neq$ & $\neq$ & $\neq$ & 456 & $\neq$ & $\neq$ & $\neq$ & $\neq$ \\
\hline 373 & + & - & $\neq$ & $\neq$ & 461 & + & \pm & $\mp$ & - \\
\hline 381 & $\neq$ & + & $\neq$ & $\neq$ & 464 & + & $\bar{t}$ & $\neq$ & $\neq$ \\
\hline 382 & $\neq$ & $\neq$ & $\neq$ & + & 465 & + & $\mp$ & + & $\mp$ \\
\hline 383 & + & - & + & + & 477 & $\mp$ & $\mp$ & $\mp$ & - \\
\hline 394 & $\neq$ & + & + & + & 479 & + & + & $\mp$ & $\mp$ \\
\hline
\end{tabular}

Explanation of symbols in table:

Two readings were made of each test at the expiration of 24 and 48 hours, respectively. Only final readings were entered.

Two dilutions were made by adding $0.02 \mathrm{mil}$ and $0.01 \mathrm{mil}$ of serum respectively, to $1 \mathrm{mil}$ of antigen.

- indicates no evidence of reaction.

$\mp$ indicates slight sediment but supernatant fluid turbid.

\pm indicates more sediment than $\mp$ but still a faint cloudiness in supernatant fluid.

F indicates that after over-night incubation complete agglutination is present.

+ indicates that after over-night incubation there was not complete agglutination, but on standing for 24 hours longer the fluid cleared up.

5. Partial agglutination with both Bact. pullorum and Bact. sanguinarium antigens was obtained with three samples (Nos. 325, 432, 477). Repetition of the tests with these samples gave the same results.

6. Complete agglutination with Bact. pullorum antigen but none with Bact sanguinarium antigen was obtained with three samples (Nos. 349, 350, 423). Repetition of the tests with these samples gave the same results.

The results of the agglutination test indicated that the reacting birds were infected either with both Bact. pullorum and Bact. sanguinarium or with one of the two species alone, but did not make it possible to arrive at a more definite conclusion. In order that information on this point might be obtained 29 of the 32 reactors were secured 
for autopsy. The three reactors not obtained were numbers 315,435 , and 452 , all of which had reacted positively with both antigens. The birds obtained were examined for abnormalities, particularly of the ovary. Cultures were made from the livers, spleens, ovaries, and normal and abnormal-appearing ovules and yolks. The results of the autopsies and bacteriologic examinations appear in table 3.

\section{DISCUSSION OF POST-MORTEM AND BACTERIOLOGICAL FINDINGS}

Abnormal ovaries were found in all of the twenty-nine reacting hens examined. The abnormalities of the ovaries included bloody or caseated ovules; yolks varying from a pea to a hazelnut in size with a thick opaque capsule containing yellow semi-solid oily material or a clear yellow oily liquid with white flakes in suspension; small partially solidified, blood-tinged yolks; yolks of various sizes with capsule but partially filled with a thick yellow or greenish-yellow liquid; solidified angular yellow or greenish-yellow or blood-tinged yolks; and a number of small cysts attached to the ovary.

No correlation was found to exist between the degree of reaction to agglutination test of the blood serum of the birds and the extent of ovarian abnormalities present. For example, serum from bird 395 in which only slight ovarian abnormalities were found, caused complete agglutination in both dilutions with both antigens, while serum from bird 416, in which extensive abnormalities of the ovaries were found, produced partial agglutination in the 1-50 dilution with the pullorum antigen, complete agglutination in the 1-50 dilution with the sanguinarium antigen, but no agglutination in the 1-100 dilution with either antigen.

In addition to abnormalities of the ovaries, in seven birds yolk material was found in the abdominal cavity. In three of these (365, $416,456)$ the material had the appearance of having escaped from a recently ruptured yolk. In the other four cases $(341,350,383,423$ ) the material was solidified or encapsulated indicating that it had been in the abdominal cavity for some time. In two other birds (354, 464) there was no free yolk material in the abdominal cavity but the peritoneum was thickened and opaque suggesting that rupture of a yolk had previously occurred in these birds. The owner stated that a number of the flock had died from ruptured yolk during the preceding laying season. None of the latter were given a bacteriological examination so it is not known that Bact. sanguinarium was associated with 


\begin{tabular}{|c|c|c|c|c|c|c|c|c|c|}
\hline & & 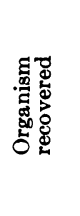 & 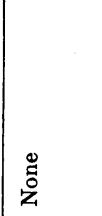 & 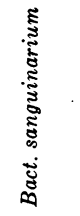 & 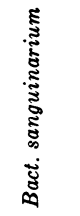 & 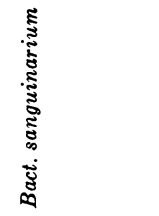 & 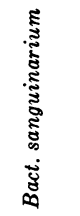 & 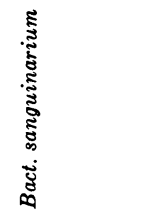 & 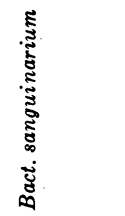 \\
\hline & & 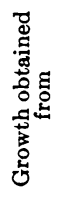 & $\begin{array}{l}0 \\
\text { : } \\
\text { z }\end{array}$ & 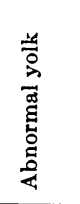 & 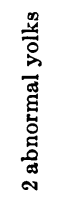 & 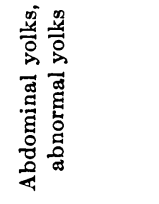 & 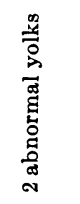 & 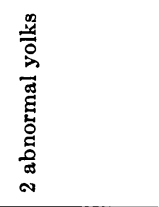 & 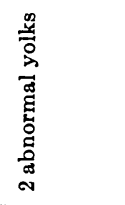 \\
\hline 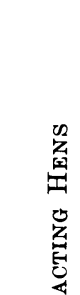 & & 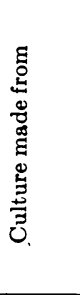 & 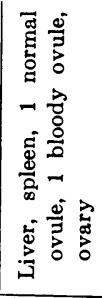 & 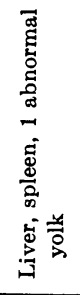 & 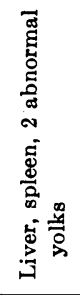 & 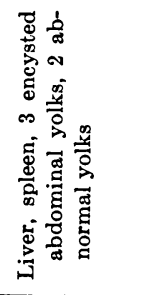 & 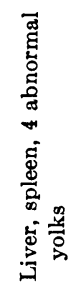 & 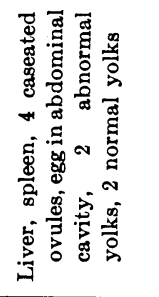 & 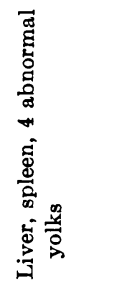 \\
\hline 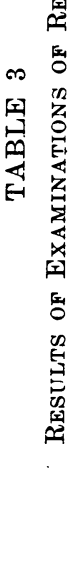 & & 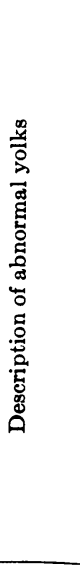 & 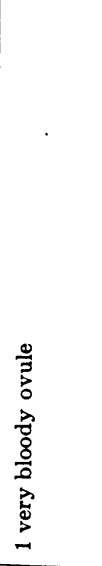 & 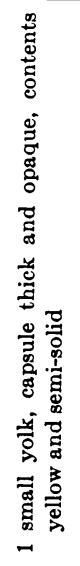 & 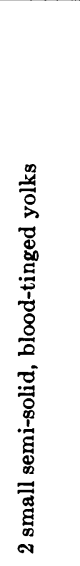 & 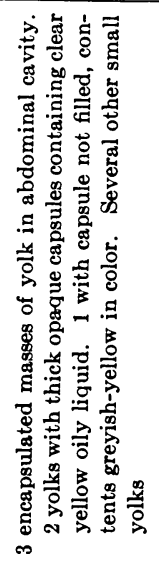 & 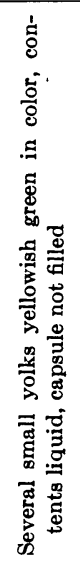 & 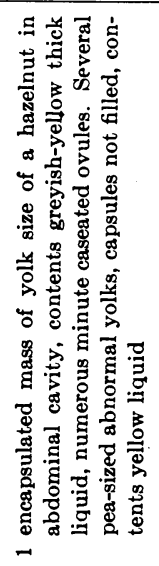 & 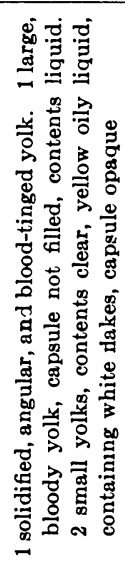 \\
\hline & & 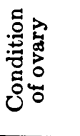 & 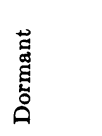 & 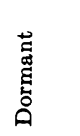 & 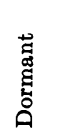 & 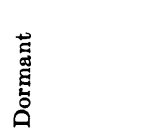 & $\begin{array}{l}\vec{\Xi} \\
\text { : } \\
\text { مٌ }\end{array}$ & 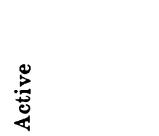 & 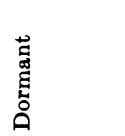 \\
\hline & 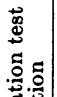 & 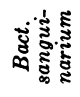 & + & $\underset{H}{H}$ & $\stackrel{\text { I }}{\text { H }}$ & H & 1 & i & H \\
\hline & 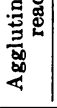 & बू. & $\stackrel{\sharp}{+}$ & $\stackrel{+}{H}$ & H & H & + & + & H \\
\hline & & & ర్లి & శ్లి & జ్ల & Fे & 罚 & 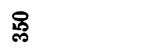 & 芦 \\
\hline
\end{tabular}


March, 1927] Beach-Davis: Infection of Chicks by Fowl-Typhoid Organism 419

\begin{tabular}{|c|c|c|c|c|c|c|c|c|}
\hline \multicolumn{2}{|c|}{ 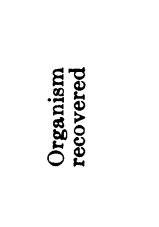 } & 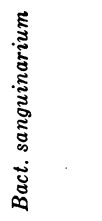 & 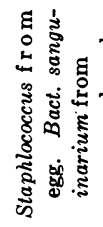 & 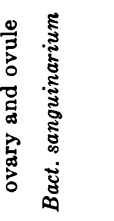 & 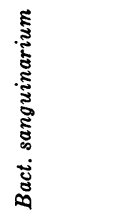 & 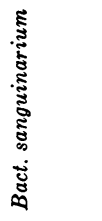 & 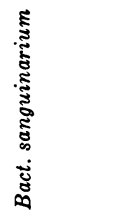 & 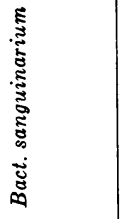 \\
\hline \multicolumn{2}{|c|}{ 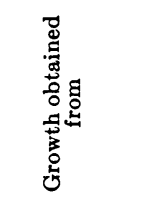 } & 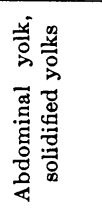 & 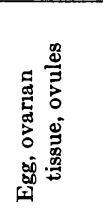 & 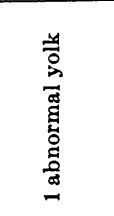 & 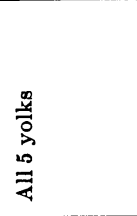 & 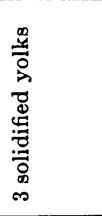 & 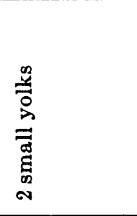 & 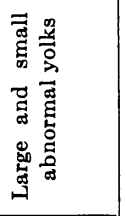 \\
\hline & 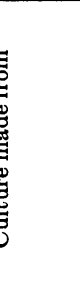 & 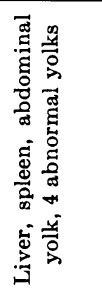 & 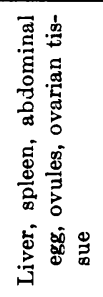 & 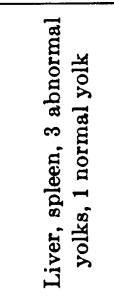 & 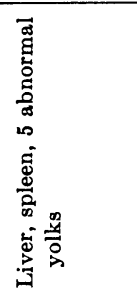 & 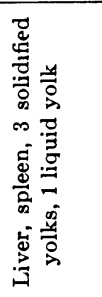 & 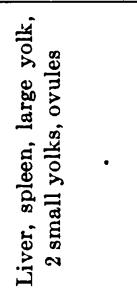 & 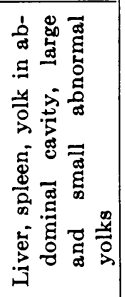 \\
\hline \multicolumn{2}{|c|}{ 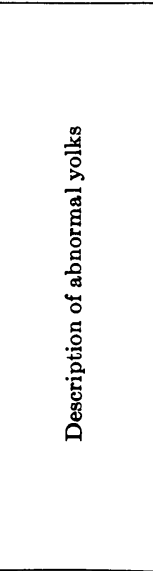 } & 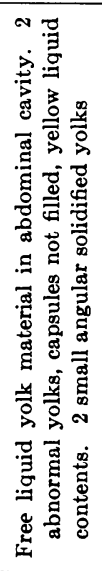 & 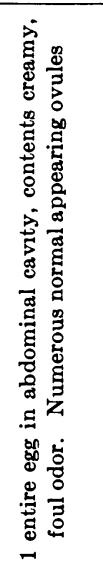 & 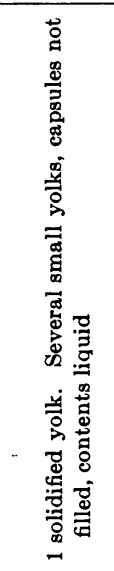 & 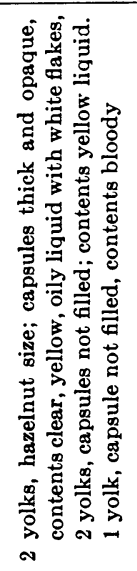 & 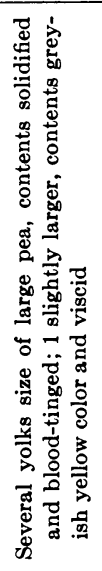 & 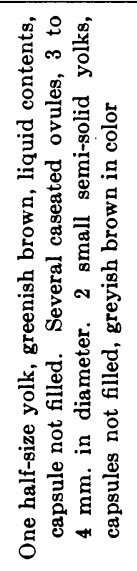 & 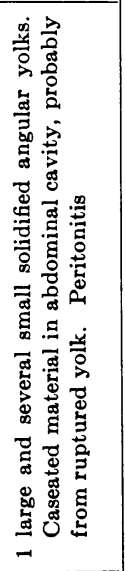 \\
\hline \multicolumn{2}{|c|}{ 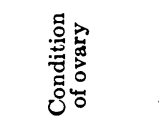 } & 䒿 & 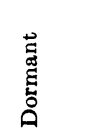 & 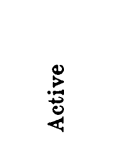 & 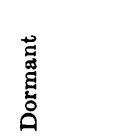 & 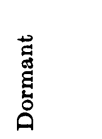 & 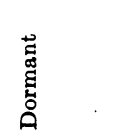 & 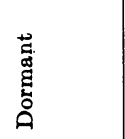 \\
\hline \multirow{2}{*}{ 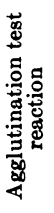 } & 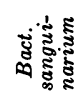 & H & $\stackrel{+}{H}$ & H & H & H & + & + \\
\hline & 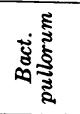 & + & + & H & + & $\stackrel{+}{H}$ & H & + \\
\hline \multicolumn{2}{|c|}{ 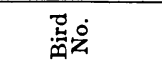 } & : & $\stackrel{\circ}{\circ}$ & ह & 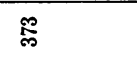 & $\overrightarrow{\Phi_{\infty}}$ & ळ్ల & $\underset{ల}{\mathscr{m}}$ \\
\hline
\end{tabular}




\begin{tabular}{|c|c|c|c|c|c|c|c|c|c|}
\hline & 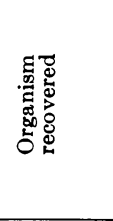 & 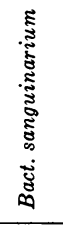 & $\begin{array}{l}0 \\
\check{Z} \\
\check{z}\end{array}$ & 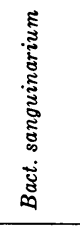 & 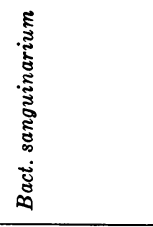 & 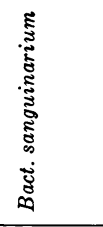 & 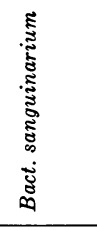 & 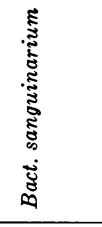 & 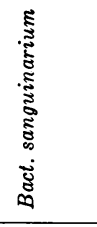 \\
\hline & 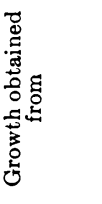 & 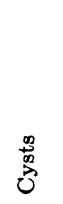 & 芩 & 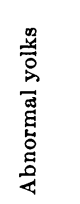 & 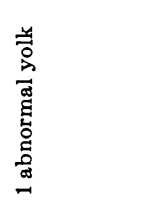 & 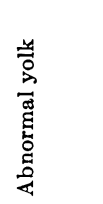 & 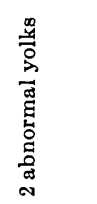 & 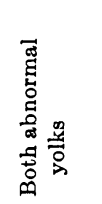 & 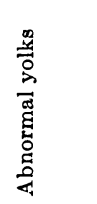 \\
\hline & 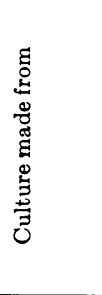 & 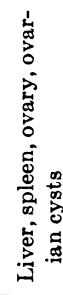 & 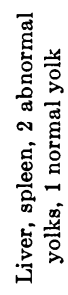 & 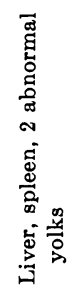 & 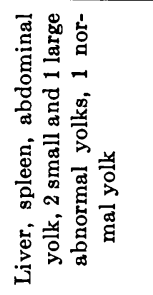 & 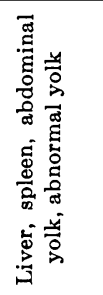 & 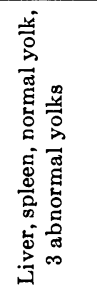 & 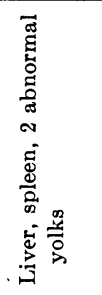 & 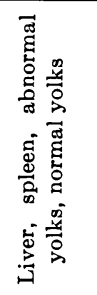 \\
\hline & 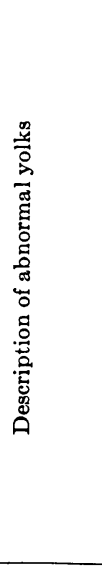 & 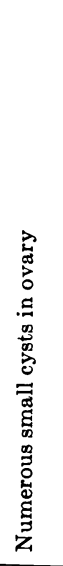 & 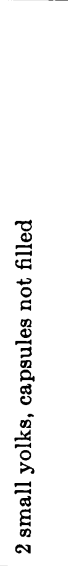 & 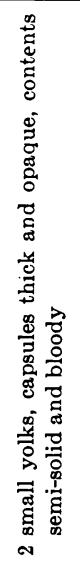 & 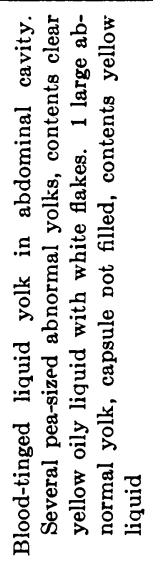 & 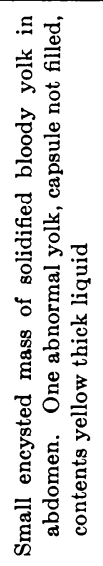 & 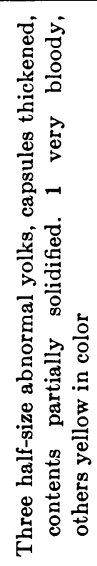 & 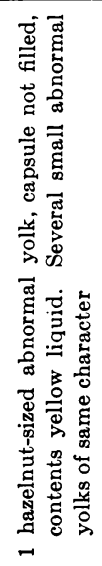 & 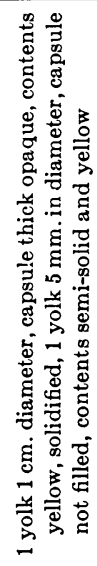 \\
\hline & 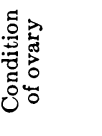 & 莺 & : & 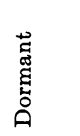 & 总 & 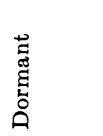 & 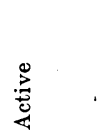 & 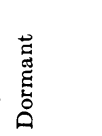 & 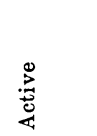 \\
\hline 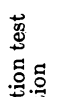 & 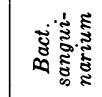 & + & + & + & + & i & H & $\begin{array}{l}1 \\
H\end{array}$ & $\begin{array}{l}H \\
+\end{array}$ \\
\hline 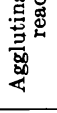 & हूँ & $\underset{H}{+}$ & + & $\begin{array}{l}1 \\
+\end{array}$ & $\begin{array}{l}1 \\
H\end{array}$ & $\stackrel{H}{+}$ & $\stackrel{+}{H}$ & $\underset{H}{H}$ & + \\
\hline & & 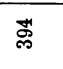 & $\stackrel{\text { 号 }}{ }$ & $\stackrel{20}{F}$ & $\stackrel{\circ}{\not}$ & ॠ & $\stackrel{4}{*}$ & $\widetilde{F}$ & $\Re$ \\
\hline
\end{tabular}




\begin{tabular}{|c|c|c|c|c|c|c|c|c|}
\hline & 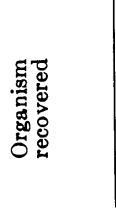 & 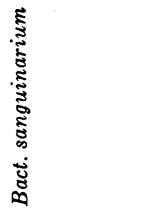 & 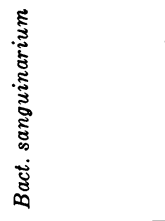 & 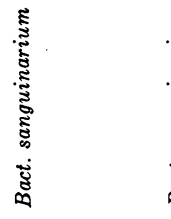 & 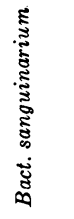 & 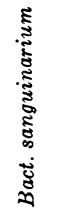 & 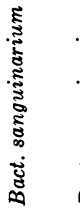 & 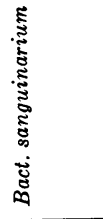 \\
\hline 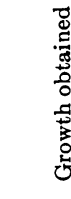 & & 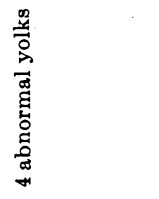 & 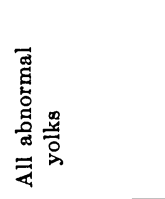 & 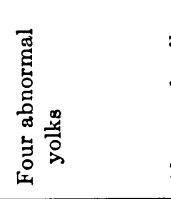 & 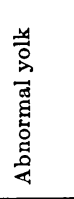 & 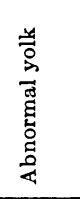 & 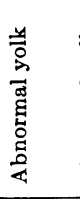 & 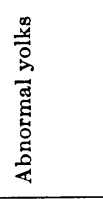 \\
\hline & 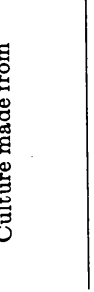 & 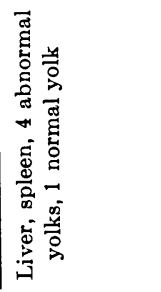 & 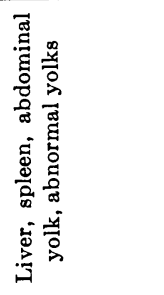 & 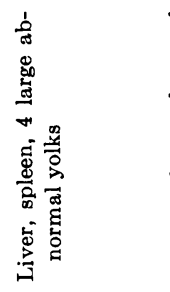 & 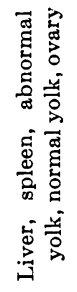 & 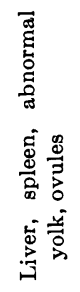 & 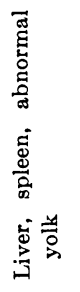 & 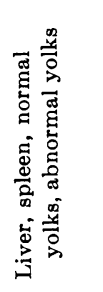 \\
\hline & 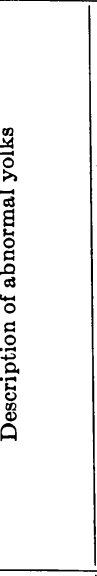 & 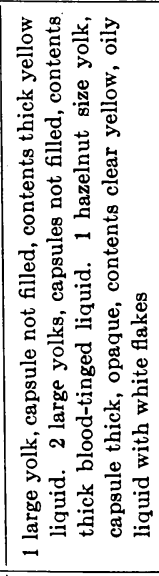 & 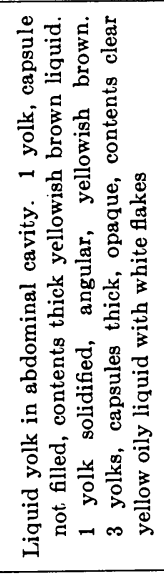 & 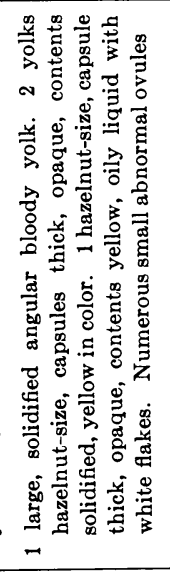 & 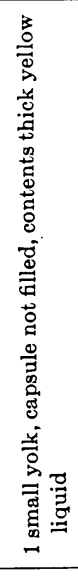 & 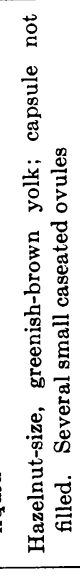 & 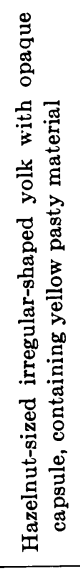 & 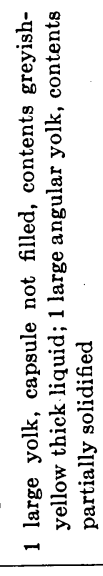 \\
\hline & 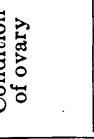 & 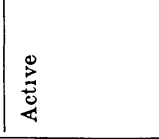 & 总 & : & 总 & 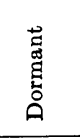 & $\begin{array}{l}\overrightarrow{\mathrm{E}} \\
\text { हू̆ } \\
\stackrel{\circ}{\circ}\end{array}$ & 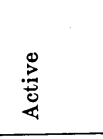 \\
\hline 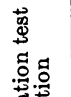 & 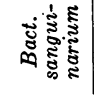 & H & \# & I & H & $\stackrel{+}{+}$ & H & H \\
\hline 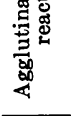 & 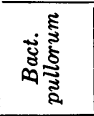 & $\stackrel{+}{+}$ & H & + & + & $\stackrel{H}{+}$ & \# & \pm \\
\hline & & $\$$ & \& & $\vec{\phi}$ & तु & 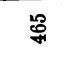 & 워 & of \\
\hline
\end{tabular}


the losses at that time. However, since Bact. sanguinarium is frequently found associated with ruptured yolk, and ovarian infection with the organism was found to exist in the flock, it seems possible that Bact. sanguinarium was present at the time the deaths from ruptured yolk occurred and that the ovarian infection may have become established at that time.

Bact. sanguinarium was isolated from abnormal yolks, ovules, or cysts in all except 2 of the 29 birds. Included with those from which Bact. sanguinarium was isolated were the three birds (Nos. 349, 350, 423) whose blood serum had given a positive agglutination reaction with Bact. pullorum antigen and a negative reaction with Bact. sanguinarium antigen. The abnormalities of the ovaries in the two birds (Nos. 304 and 395) from which Bact. sanguinarium was not isolated, were very slight, consisting of one small, bloody ovule in bird No. 304 and two small, flabby yolks in bird No. 395 . Failure to isolate Bact. sanguinarium from these two cases does not necessarily prove, however, that the organism was not present, since it is possible that it was present and that we failed to recover it in cultures.

\section{GENERAL DISCUSSION}

These studies demonstrate that Bact. sanguinarium may produce an acute, highly fatal disease of young chicks and a chronic infection of the ovaries of hens which cannot be differentiated from disease of chicks and ovarian infection of hens caused by Bact. pullorum, except by the difference in the cultural characteristics of the organism isolated from affected birds. Agglutinins occur in the blood serum of hens that are infected with Bact. sanguinarium. However, the ordinary routine agglutination test does not serve to differentiate between ovarian infection with Bact. sanguinarium and Bact. pullorum because serum from a hen infected with the former will cause agglutination of antigens prepared from either of the two species of organisms. This cross-agglutination makes it possible to detect carriers of either Bact. sanguinarium or Bact. pullorum by an agglutination test employing Bact. pullorum antigen. It may, therefore, be considered as enhancing rather than detracting from the value of the agglutination test in the detection of adult hens that harbor infection that may be transmitted through the medium of eggs to offspring.

Although Bact. sanguinarium was not isolated from eggs laid by infected hens, these studies furnish evidence that this organism, like Bact. pullorum, is transmitted directly to chicks through eggs laid 
by infected adults. Deaths among the chicks from Bact. sanguinarium infection began when they were 60 hours old. It seems quite certain that the chicks did not acquire the infection from contaminated brooder houses or hovers and very unlikely that the infection originated in the incubators or shipping boxes. The only remaining source of infection is the parent stock among which chronic ovarian infection with Bact. sanguinarium was found to exist. It seems probable, therefore, that some of the eggs laid by these hens contained Bact. sanguinarium, which resulted in infection of the chicks hatched from them.

The origin of chronic infection of the ovaries of the hens with Bact. sanguinarium remains undetermined. It has been found that chicks that survive an outbreak of disease due to infection with Bact. pullorum may continue to harbor the infection and that it usually becomes localized in the ovaries. Observations made on 25 of the 66 chicks that survived the infection with Bact. sanguinarium and were kept for one year, however, failed to show that any of them had become carriers of the organism. It is in this particular only that these studies fail to show that the behavior of Bact. sanguinarium in either chicks or adult fowls may be the same as that of Bact. pullorum. The facts that losses from ruptured yolk had occurred in the flock of hens a year before the studies herein reported were made and that Bact. sanguinarium infection is frequently associated with ruptured yolk, suggest that the ovarian infection with Bact sanguinarium may have then become established. However, no bacteriological examination of dead birds from this flock had ever been made and it was not known that Bact. sanguinarium existed in it before the agglutination tests were made. 


\section{BIBLIOGRAPHY}

1 KLEIN, E.

1889. Über eine epidemische Krankheit der Huhner verusacht durch einem Bacillus-Bacillus gallinarum. Centralbl. f. Bakteriol. 5: 688-693.

2 MOORE, V. A.

1896. Infectious leukemia of fowls. U. S. D. A., Bur. Animal Ind. Annual Rept. 1895-1896: 187-205.

3 TAYLOR, W. J.

1916. An outbreak of fowl typhoid. Jour. Amer. Vet. Med. Assoc., 49: $35-49$.

4 Smith, T., and C. Tenbroeck

1915. A note on the relation between $B$. pullorum (Rettger) and the fowl typhoid bacillus (Moore). Jour. Med. Res. 31: 547-555.

5 RetTiaer, L. F., ANd S. A. Koser

1917. A comparative study of Bact. pullorum (Rettger) and Bact. sanguinarium (Moore). Jour. Med. Res. 35: 443-458.

6 Goldberg, S. A.

1917. A study of the fermenting properties of Bact. pullorum (Rettger) and Bact. sanguinarium (Moore). Jour. Amer. Vet. Med. Assoc. 51: 203-210.

7 Hadley, P. B.

1918. The colon-typhoid intermediates as causative agents of disease in birds. Rhode Island Agr. Exp. Sta. Bul. 174: 1-216.

8 Panisset, M. L., ANd J. Verge

1924. Sur une epizooti de diarrhee blanche bacillaire des poissons. Rev. Gen. Med. Vet. 23: 19-21.

9 BeAudette, F. R.

1925. The possible transmission of fowl typhoid through the hen's egg. Jour. Amer. Vet. Med. Assoc. 20: 741-745.

10 DOYLE, T. M.

1926. The method of transmission of avian typhoid. Jour. Comp. Path. and Therap. 39: 137-140.

Transmitted December, 1926. 


\section{BULLETINS}

No.

253. Irrigation and Soil Conditions in the Sierra Nevada Foothills, California.

261. Melaxuma of the Walnut, "Juglans regia."

262. Citrus Diseases of Florida and Cuba Compared with Those of California.

263. Size Grades for Ripe Olives.

268. Growing and Grafting Olive Seedlings.

273. Preliminary Report on Kearney Vineyard Experimental Drain.

275. The Cultivation of Belladonna in California.

276. The Pomegranate.

277. Sudan Grass.

278. Grain Sorghums.

279. Irrigation of Rice in California.

283. The Olive Inserts of California.

294. Bean Culture in California.

304. A Study of the Effects of Freezes on Citrus in California.

310. Plum Pollination.

312. Mariout Barley.

313. Pruning Young Deciduous Fruit Trees.

319. Caprifigs and Caprification.

324. Storage of Perishable Fruit at Freezing Temperatures.

325. Rice Irrigation Measurements and Experiments in Sacramento Valley, 1914-1919.

328. Prune Growing in California.

331. Phylloxera-Resistant Stocks.

335. Cocoanut Meal as a Feed for Dairy Cows and Other Livestock.

339. The Relative Cost of Making Logs from Small and Large Timber.

340. Control of the Pocket Gopher in California.

343. Cheese Pests and Their Control.

344. Cold Storage as an Aid to the Marketing of Plums.

346. Almond Pollination. uous Orchards.

348. Pruning Young Olive Trees.

349. A Study of Sidedraft and Tractor Hitches.

350. Agriculture in Cut-over Redwood Lands.

352. Further Experiments in Plum Pollination.

353. Bovine Infectious Abortion.

354. Results of Rice Experiments in 1922.

357. A Self-mixing Dusting Machine for Applying Dry Insecticides and

358. Black Measles, Water Berries, and Related Vine Troubles.

361. Preliminary Yield Tables for Second Growth Redwood.

362. Dust and the Tractor Engine.

363. The Pruning of Citrus Trees in California.

364. Fungicidal Dusts for the Control of Bunt.

365. Avocado Culture in California.

366. Turkish Tobacco Culture, Curing and Marketing.

367. Methods of Harvesting and Irrigation in Relation of Mouldy Walnuts.

368. Bacterial Decomposition of Olives during Pickling.

369. Comparison of Woods for Butter Boxes.
No.

370. Browning of Yellow Newtown Apples.

371. The Relative Cost of Yarding Small and Large Timber.

372. The Cost of Producing Market Milk and Butterfat on 246 California Dairies.

373. Pear Pollination.

374. A Survey of Orchard Practices in the Citrus Industry of Southern California.

375. Results of Rice Experiments at Cortena, 1923.

376. Sun-Drying and Dehydration of Wal nuts.

377. The Cold Storage of Pears.

379. Walnut Culture in California.

380. Growth of Eucalyptus in California Plantations.

381. Growing and Handling Asparagus Crowns.

382. Pumping for Drainage in the San Joaquin Valley, California.

383. Monilia Blossom Blight (Brown Rot) of Apricot.

385. Pollination of the Sweet Cherry.

386. Pruning Bearing Deciduous Fruit Trees.

387. Fig Smut

388. The Principles and Practice of Sundrying Fruit.

389. Berseem or Egyptian Clover

390. Harvesting and Packing Grapes in California.

391. Machines for Coating Seed Wheat with Copper Carbonate Dust.

392. Fruit Juice Concentrates.

393. Crop Sequences at Davis.

394. Cereal Hay Production in California. Feeding Trials with Cereal Hay.

395. Bark Diseases of Citrus Trees.

396. The Mat Bean (Phaseolus aconitifolius).

397. Manufacture of Roquefort Type Cheese from Goat's Milk.

398. Orchard Heating in California.

399. The Blackberry Mite, the Cause of Redberry Disease of the Himalays Blackberry, and its Control.

400. The Utilization of Surplus Plims.

401. Cost of Work Horses on California Farms.

402. The Codling Moth in Walnuts.

403. Farm-Accounting Associations.

404. The Dehydration of Prunes.

405. Citrus Culture in Central California.

406. Stationary Spray Plants in California.

407. Yield, Stand and Volume Tables for White Fir in the California Pine Region.

408. Alternaria Rot of Lemons.

409. The Digestibility of Certain Fruit By. products as Determined for Rumi. nants.

410. Factors Affecting the Quality of Fresh Asparagus after it is Harvested.

411. Paradichlorobenzene as a Soil Fumigant.

412. A Study of the Relative Values of Certain Root Crops and Salmon Oil as Sources of Vitamin A for Poultry.

413. The California Poultry Industry; a Statistical Study.

414. Planting and Thinning Distances for Deciduous Fruit Trees. 


\section{CIRCULARS}

No.

87. Alfalfa.

117. The Selection and Cost of a Small Pumping Plant.

127. House Fumigation.

129. The Control of Citrus Insects.

136. Melilotus indica as a Green-Manure Crop for California.

144. Oidium or Powdery Mildew of the Vine.

157. Control of the Pear Scab.

160. Lettuce Growing in California.

164. Small Fruit Culture in California.

166. The County Farm Bureau.

170. Fertilizing California Soils for the 1918 Crop.

173. The Construction of the Wood-Hoop Silo.

178. The Packing of Apples in California.

179. Factors of Importance in Producing Milk of Luow Bacterial Count.

190. Agriculture Clubs in California.

199. Onion Growing in California.

202. County Organizations for Rural Fire Control.

203. Peat as a Manure Substitute.

209. The Function of the Farm Bureau.

210. Suggestions to the Settler in California.

212. Salvaging Rain-Damaged Prunes.

215. Feeding Dairy Cows in California.

217. Methods for Marketing Vegetables in California.

220. Unfermented Fruit Juices.

228. Vineyard Irrigation in Arid Climates.

230. Testing Milk, Cream, and Skim Milk for Butterfat.

231. The Home Vineyard.

232. Harvesting and Handling California Cherries for Eastern Shipment.

234. Winter Injury to Young Walnut Trees during 1921-22.

235. Soil Analysis and Soil and Plant Inter-relations.

236. The Common Hawks and Owls of California from the Standpoint of the Rancher.

237. Directions for the Tanning and Dressing of Furs.

238. The Apricot in California.

239. Harvesting and Handling Apricots and Plums for Eastern Shipment.

240. Harvesting and Handling Pears for Eastern Shipment.

241. Harvesting and Handling Peaches for Eastern Shipment.

243. Marmalade Juice and Jelly Juice from Citrus Fruits.

244. Central Wire Bracing for Fruit Trees.

245. Vine Pruning Systems.

247. Colonization and Rural Development.

248. Some Common Errors in Vine Pruning and Their Remedies.

249. Replacing Missing Vines.

250. Measurement of Irrigation Water on the Farm.

252. Supports for Vines.

253. Vineyard Plans.

254. The Use of Artificial Light to Increase Winter Egg Production.
255. Leguminous Plants as Organic Fertilizer in California Agriculture.

256. The Control of Wild Morning Glory.

257. The Small-Seeded Horse Bean.

258. Thinning Deciduous Fruits.

259. Pear By-products.

261. Sewing Grain Sacks.

262. Cabbage Growing in California.

263. Tomato Production in California.

264. Preliminary Essentials to Bovine Tuberculosis Control.

265. Plant Disease and Pest Control

266. Analyzing the Citrus Orchard by Means of Simple Tree Records.

267. The Tendency of Tractors to Rise in Front: Causes and Remedies.

269. An Orchard Brush Burner.

270. A Farm Septic Tank.

272. California Farm Tenancy and Methods of Leasing.

273. Saving the Gophered Citrus Tree.

274. Fusarium Wilt of Tomato and its Control by Means of Resistant Varieties.

276. Home Canning.

277. Head, Cane, and Cordon Pruning of Vines.

278. Olive Pickling in Mediterranean Countries.

279. The Preparation and Refining of Olive Oil in Southern Europe.

281. The Results of a Survey to Determine the Cost of Producing Beef in California.

282. Prevention of Insect Attack on Stored Grain.

283. Fertilizing Citrus Trees in California.

284. The Almond in California.

285. Sweet Potato Production in California.

286. Milk Houses for California Dairies.

287. Potato Production in California.

288. Phylloxera Resistant Vineyards.

289. Oak Fungus in Orchard Trees.

290. The Tangier Pea.

291. Blackhead and Other Causes of Loss of Turkeys in California.

292. Alkali Soils.

293. The Basis of Grape Standardization.

294. Propagation of Deciduous Fruits.

295. The Growing and Handling of Head Lettuce in California.

296. Control of the California Ground Squirrel.

298. The Possibilities and Limitations of Coöperative Marketing.

299. Poultry Breeding Records.

300. Coccidiosis of Chickens.

301. Buckeye Poisoning of the Honey Bee.

302. The Sugar Beet in California

303. A Promising Remedy for Black Measles of the Vine.

304. Drainage on the Farm.

305. Liming the Soil.

306. A General Purpose Soil Auger and its Use on the Farm.

307. American Foulbrood and its Control.

308. Cantaloupe Production in California.

The publications listed above may be had by addressing

College of Agriculture,

University of California,

Berkeley, California. 
The titles of the Technical Papers of the California Agricultural Experiment Station, Nos. 1 to 20, which HILGARDIA replaces, and copies of which may be had on application to the Publication Secretary, Agricultural Fxperiment Station, Berkeley, are as follows:

1. The Removal of Sodium Carbonate from Solls, by Walter P. Kelley and Fdward E. Thomas. January, 1923.

3. The Formation of Sodium Carbonate in Soils, by Arthur B. Cummins and Walter P. Kelley. March, 1923.

4. Iffect of Sodium Chlorid and Calcium Chlorid upon the Growth and Composition of Young Orange Trees, by $H . S$. Reed and A. R. C. Haas. April, 1923.

5. Citrus Blast and Black Pit, by H. S. Fawcett, W. T. Horne, and A. F. Camp. May, 1923.

6. A Study of Deciduous Fruit Tree Rootstocks with Special Reference to Their Identification, by Myer J. Heppner. June, 1923.

7. A Study of the Darkening of Apple Tissue, by F. L. Overholser and W. $\nabla$. Cruess. June, 1923.

8. Effect of Salts on the Intake of Inorganic Elements and on the Buffer System of the Plant, by D. R. Hoagland and J. C. Martin. July, 1923.

9. Fxperiments on the Reclamation of Alkali Soils by Ieaching with Water and Gypsum, by P. I. Hibbard. Angust, 1923.

10. The Seasonal Variation of the Soil Moisture in a Walnut Grove in Relation to Hygroscopic Coefficient, by I. D. Batchelor and H. S. Reed. September, 1923.

11. Studies on the Fffects of Sodium, Potassium, and Galcium on Young Orange Trees, by H. S. Reed and A. R. C. FHaas. October, 1923.

12. The Effect of the Plant on the Reaction of the Culture Solution, by $\mathbf{D} . \mathbf{R}$. Hoagland. November, 1923.

13. Some Mutual Fffects on Soil and Plant Induced by Added Solutes, by John S. Burd and J. C. Martin. December, 1923.

14. The Respiration of Potato Tubers in Relation to the Occurrence of Blackheart, by J. P. Bennett and I. T. Bartholomew. January, 1924.

15. Replaceable Bases in Solls, by Walter P. Kelley and S. Melvin Brown. February, 1924.

16. The Moisture Equivalent as Infinenced by the Amount of Soil Used in its Determination, by $\mathbf{F}$. J. Veihmeyer, O. W. Israelsen and J. P. Conrad. September, 1924.

17. Nutrient and Toxic Fffects of Certain Ions on Citrus and Walnut Trees with Especial Reference to the Concentration and Ph of the Medium, by H. S. Reed and A. R. C. Haas. October, 1924.

18. Factors Influencing the Rate of Germination of Seed of Asparagus offlinalis, by H. A. Borthwick. March, 1925.

19. The Relation of the Subcutaneous Administration of Iiving Bacterium abortum to the Immunity and Carrier Problem of Bovino Infectious Abortion, by George H. Hart and Jacob Traum. April, 1925.

20. A Study of the Conductive Tissues in Shoots of the Bartlett Pear and the Relationship of Food Movement to Dominance of the Apical Buds, by Frank E. Gardner. April, 1925. 